\title{
GERMINATION AND VIGOR OF LETTUCE SEEDS UNDER DIFFERENT TEMPERATURES
}

Patricia Aparecida Maia Soares ${ }^{1}$, Andreia Márcia Santos de Souza David ${ }^{1}$, Dayana Lucia Mota Pinheiro Bernardino ${ }^{1}$, Renato de Azevedo Quintino ${ }^{1}$, João Paulo Nunes Lacerda ${ }^{1} \&$ Fernando Gomes da Silva ${ }^{1}$

\footnotetext{
${ }^{1}$ Universidade Estadual de Montes Claros. E-mail: patricia_maiam@hotmail.com; andreia.david@unimontes.br; dayanaluci2008@hotmail.com; renato_quintino_galo@hotmail.com;.jpnlacerda@gmail.com; nando.agro@bol.com.br
}

\begin{abstract}
The objective of this study was to evaluate the effect of temperature on germination and vigor of the seeds from different lettuce cultivars. There was influence of the lettuce grow crops on germination and seed vigor. The cultivars of the lettuce have a higher germination and vigor when exposed to $20^{\circ} \mathrm{C}$, and the Curly for daylight showed itself more tolerant to temperatures of 25 to $30^{\circ} \mathrm{C}$. The temperature of $30^{\circ} \mathrm{C}$ inhibits the germination of lettuce seeds of the American, Mimosa Salad bowl and Curly Cabbage cultivars.
\end{abstract}

Keywords: cultivars, Lactuca sativa L., thermotolerance

\section{GERMINAÇÃO E VIGOR DE SEMENTES DE ALFACE SOB DIFERENTES TEMPERATURAS}

\section{RESUMO}

O objetivo do presente trabalho foi avaliar o efeito de diferentes temperaturas na germinação e no vigor de sementes de diferentes cultivares de alface. Houve influência da cultivar de alface sobre a germinação e vigor das sementes. As cultivares de alface apresentam maior germinação e vigor quando expostas à temperatura de $20^{\circ} \mathrm{C}$, sendo que a Crespa, em relação à Verão, se mostrou mais tolerante às temperaturas de 25 e $30^{\circ} \mathrm{C}$. A temperatura de $30^{\circ} \mathrm{C}$ inibe a germinação em sementes de alface das cultivares Americana, Mimosa Salad Bowl e Crespa Repolhuda.

Palavras-chave: cultivares, Lactuca sativa L., termotolerância 


\section{INTRODUCTION}

The lettuce (Lactuca sativa L.) seeds present high sensibility to the climatic conditions. This fact brings impasses in the germination and it is responsible for the low quality and delay in the production of seedlings (BUFALO et al. 2012), once the success of the production depends, among other aspects, of the establishment of seedlings in the field. It isa determinant factor for seed germination.

The germination of the lettuce seeds is influenced by the interaction between the factors temperature and light. Before that, to know the extreme limits of temperature for germination supplies information of biological and ecological interest, because each species presents a minimum, maxim, and optimal temperature for germination. For Catão et al. (2014), the identification of genotypes capable of germinating in higher temperatures becomes of great importance tothe tropical areas, regarding the attainmentof cultivates more tolerant and a better quality, as well as for the germination.

As a result of the cultivar, the lettuce seeds may present thermoinhibition or thermodormity and do not germinate when exposed to high temperatures during soaking, due to the stiffening of the endosperm that finishes the protrusion of the radicle (NASCIMENTO et al., 2012). Thus, it can be inferred that cultivars germinated at high temperatures are related to the thermotolerance of the seed.

Nascimento et al. (2012) also emphasize that very low temperatures can alter both the speed and the final percentage of germination. However, this momentary inhibition can be eliminated from the moment the ideal temperature returns. Therefore, to identify cultivars resistant to higher temperatures is important, since it will extend the regions and times of the year for crop production and, consequently, reduce production losses.

In view of the context, the objective of this work was to evaluate the effect of different temperatures on germination and seed vigor of lettuce cultivars.

\section{MATERIAL AND METHODS}

The experiment was conducted at the Laboratory of Seed Analysis of the Department of Agrarian Sciences of the State University of Montes Claros - UNIMONTES, Campus de Janaúba, in the state of Minas Gerais, Brazil. The seeds of lettuce (Lactuca sativa L.) used in the study were obtained from the local.

The experimental design was completely randomized in a $4 \times 4$ factorial scheme, with four treatments (American, Curly for Summer, Mimosa Salad Bowl, and Curly Cabbage) and four temperatures $\left(20,25,30\right.$, and $\left.35^{\circ} \mathrm{C}\right)$, with four replicates of 50 seeds per treatment. The effects of the 272 
treatments were evaluated by germination and vigor tests (first germination count, germination rate index).

The germination test was carried out in Gerbox-type plastic boxes with two germitest paper sheets previously moistened with distilled water, equivalent to 2,5 times the dry paper weight (BRASIL, 2009). The boxes containing the seeds were kept in germinators previously regulated at temperatures of 20, 25, 30 , and $35^{\circ} \mathrm{C}$ under constant light. Evaluations were carried out at 7 days after sowing, and the results were expressed as percentage of normal seedlings, when the percentage of dormant seeds was also evaluated.

The first germination count consisted of recording the percentage of normal seedlings obtained on the 4th day after the start of the germination test (BRASIL, 2009).

The germination speed index was carried out in conjunction with the germination test, recording the number of seedlings with a visible cotyledonous handle up to 7 days after sowing at the same time. At the end of the test, with the daily data of the number of seedlings emerged, the germination speed index was calculated, using the formula proposed by Maguire (1962).

The studied variables were analyzed through the statistical program SISVAR (FERREIRA, 2008). The results were submitted to analysis of variance and " $F "$ test, and the significant characteristics at $5 \%$ level were submitted to the Tukey test, also at a $5 \%$ level of significance.

\section{RESULTS AND DISCUSSION}

The temperature was evaluated at $35^{\circ} \mathrm{C}$, however, the results showed that the germination of lettuce seeds was inhibited, independent of the cultivar studied, so the data were not submitted to analysis of variance. According to Nascimento et al. (2012), for most genotypes of lettuce, temperatures above $30^{\circ} \mathrm{C}$ causes inhibition of seed germination.

According to the data (Table 1), it was observed that there was interaction effect between the cultivar (C) and temperature (T) factors for all variables analyzed.

Table 1. Summary of variance analysis of the first germination count (FGC), germination (GER), germination speed index (GSI) and dormant seeds (DS) of lettuce cultivars at different temperatures. Janaúba - MG, 2015/2016. 


\begin{tabular}{|c|c|c|c|c|c|}
\hline \multirow{2}{*}{ Source of variation } & \multirow{2}{*}{ GL } & \multicolumn{4}{|c|}{ Mean squares } \\
\hline & & FGC & GER & GSI & DS \\
\hline Growcrops (C) & 2 & $16517,333 * *$ & $23694,250 * *$ & $1794,150 * *$ & $34447,583 * *$ \\
\hline Temperature $(\mathrm{T})$ & 3 & $872,889 * *$ & $860,972 * *$ & $96,522 * *$ & $2122,333 * *$ \\
\hline $\mathrm{C} \times \mathrm{T}$ & 6 & $922,889 * *$ & $1327,472 * *$ & $90,408 * *$ & $695,917 * *$ \\
\hline Residue & 36 & 39,333 & 18,972 & 4,066 & 92,500 \\
\hline Total & 47 & & & & \\
\hline $\mathrm{CV}(\%)$ & & 14,31 & 8,08 & 15,23 & 24,09 \\
\hline Overall average & & 43,83 & 53,87 & 13,24 & 39,92 \\
\hline
\end{tabular}

**Significant in the $\mathrm{F}$ Test at 5\%.

The interaction of the cultivars $\mathrm{C}$ and $\mathrm{T}$, showing the cultivar effect within each temperature (Table 2), showed that at the temperature of $20^{\circ} \mathrm{C}$, the cultivars Mimosa Salad Bowl and Curly Cabbage presented the highest germination percentages. Values above $90 \%$ were obtained. This percentage is above the minimum recommended standard for commercialization of basic seeds for this species, which is $80 \%$ (BRASIL, 2009).

Table 2. Germination (\%) of seeds of lettuce cultivars at different temperatures. Janaúba - MG, 2015/2016.

\begin{tabular}{ccccc}
\hline \multirow{2}{*}{ Temperature $\left({ }^{\circ} \mathrm{C}\right)$} & \multicolumn{4}{c}{ Growcrops } \\
\cline { 2 - 5 } & American & Curly for Summer & $\begin{array}{c}\text { Mimosa Salad } \\
\text { Bowl }\end{array}$ & Curly cabbage \\
\hline 20 & $78 \mathrm{Ba}$ & $62 \mathrm{Cb}$ & $93 \mathrm{Aa}$ & $93 \mathrm{Aa}$ \\
25 & $47 \mathrm{Bb}$ & $80 \mathrm{Aa}$ & $74 \mathrm{Ab}$ & $82 \mathrm{Ab}$ \\
30 & $0 \mathrm{Bc}$ & $40 \mathrm{Ac}$ & $0 \mathrm{Bc}$ & $0 \mathrm{Bc}$
\end{tabular}

Means followed by different letters, uppercase in the row and lowercase in the column, differ by the Tukey test at 5\% significance.

When exposed to a temperature of $25^{\circ} \mathrm{C}$, seeds of the cultivars Curly for Summer, Mimosa Salad Bowl and Curly Cabbage showed higher germination percentages, and only the seeds of Curly Cabbage cultivar maintained germination above $80 \%$ (Table 2). However, at the temperature of $30^{\circ} \mathrm{C}$ there was germination only for the cultivar Curly for Summer. These results demonstrate that the cultivar Curly for Summer has a tolerance to higher temperatures, corroborating Nascimento \& Cantliffe (2002), where 
some lettuce cultivars can germinate at temperatures ranging from 5 to $33^{\circ} \mathrm{C}$. For the other cultivars studied, the temperature of $30^{\circ} \mathrm{C}$ did not allow the germination capacity of the seeds to be expressed. Above $30^{\circ} \mathrm{C}$, seed germination of most lettuce crops is erratic or completely inhibited (NASCIMENTO et al., 2012). Under high temperatures, protein synthesis is unfavorably affected or factors involved in the regulation of endo- $\beta$ - Mannanase by the endosperm are inhibited in thermosensitive genotypes, but not in thermotolerant ones (NASCIMENTO, 2000). Under these conditions, the enzymatic endosperm can act as a physical barrier and prevent the emission of the radicle (SUNG et al., 2008).

It is worth noting that, although the germination of the Curly seeds for summer was verified, there was a $50 \%$ reduction in this variable in relation to the temperature of $25^{\circ} \mathrm{C}$. These results accord with those found by Bufalo et al. (2012), where they observed a reduction of approximately $50 \%$ in the germination of lettuce seeds of the cultivar Great Lakes American at $30^{\circ} \mathrm{C}$.

The interaction of $\mathrm{C} \mathrm{x} \mathrm{T}$, evaluating the effect of temperatures within each cultivar, showed that there was a reduction in the germination of the cultivars American, Mimosa Salad Bowl and Curly Cabbage when the temperature was elevated from 20 to $25^{\circ} \mathrm{C}$ (Table 2). The reduction of germination at high temperatures may be associated with thermodormity, because during the evaluation of the germination test, the presence of embedded seeds and without radicle protrusion were observed. Temperatures higher than the optimum for germination can promote the denaturation of essential proteins to the germination process, reflecting directly on the enzymatic reactions of the seeds, reducing not only the percentage of germination but also the speed of germination (PINHEIRO et al., 2014).

Catão et al. (2014) also observed that temperatures equal or higher than $25^{\circ} \mathrm{C}$ promoted a reduction in the germination percentage of lettuce seeds. High temperatures may decrease the solubility and binding capacity of the proteins, causing damage to both the structure of the mitochondria, reflecting the respiratory rate, and there may be a decrease in ethylene synthesis at high temperatures during seed imbibition (NASCIMENTO, 2000) reducing the germination potential of the seeds.

Only the cultivar Curly for Summer presented an increase in germination when submitted to a temperature of $25^{\circ} \mathrm{C}$ (Table 2), thus allowing to identify as a more tolerant cultivar for germination at high temperatures. For thermotolerant seeds, a greater activity of the endo- $\beta$-mannanase enzyme was observed in the endosperm before radicle emission, and this increase in enzyme activity contributed to the weakening of the endosperm, especially under conditions of high temperatures, facilitating the protrusion of the embryo and, consequently, leading to a germination condition (NASCIMENTO, 2003). 
Nascimento et al. (2012) also verified differences in seed germination of lettuce cultivars subjected to high temperatures.

The temperature of $20^{\circ} \mathrm{C}$ provided a higher germination speed of the cultivars Mimosa Salad Bowl and Curly Cabbage (Table 3). The first germination count is a simple vigor test performed simultaneously on the germination test, and assumes that the more vigorous seeds germinate more rapidly (ABUD et al., 2013).

Table 3. First germination count $(\%)$ of seeds of lettuce cultivars at different temperatures. Janaúba MG, 2015/2016.

\begin{tabular}{ccccc}
\hline & \multicolumn{4}{c}{ Growcrops } \\
\cline { 2 - 5 } Temperature $\left({ }^{\circ} \mathrm{C}\right)$ & American & Curly for Summer & $\begin{array}{c}\text { Mimosa Salad } \\
\text { Bowl }\end{array}$ & Curly Cabbage \\
\hline 20 & $66 \mathrm{Ba}$ & $54 \mathrm{Ca}$ & $74 \mathrm{ABa}$ & $81 \mathrm{Aa}$ \\
25 & $31 \mathrm{Cb}$ & $65 \mathrm{Aba}$ & $55 \mathrm{Bb}$ & $72 \mathrm{Aa}$ \\
30 & $0 \mathrm{Bc}$ & $30 \mathrm{Ab}$ & $0 \mathrm{Bc}$ & $0 \mathrm{Bb}$ \\
\hline
\end{tabular}

Means followed by different letters, uppercase in the row and lowercase in the column, differ by the Tukey test at 5\% significance.

When submitted to the temperature of $25^{\circ} \mathrm{C}$, the cultivars Curly for Summer and Curly Cabbage showed to be more vigorous. At $30^{\circ} \mathrm{C}$, only the Curly cultivar for Summer showed germination at the first count (Table 3). The fact that the other cultivars do not germinate is possibly related to the increase in temperature, since it causes innumerable physiological and biochemical changes inside the seed, among them, a greater enzymatic activity in thermotolerant genotypes compared to those thermosensitive (NASCIMENTO \& CANTLIFFE, 2001). This activity is closely related to the composition of the endosperm wall, which is determined by the genotype (CATÃO et al., 2014).In addition, these heatresistant proteins are associated with seed drying tolerance under high temperatures (KIGEL \& GALILI, 1995).

When studying the effect of temperatures within each cultivar, it is observed that the cultivars American and Mimosa Salad Bowl showed higher germination speed when submitted to $20^{\circ} \mathrm{C}$. For the cultivars Curly for Summer and Curly Cabbage, temperatures of 20 and $25^{\circ} \mathrm{C}$ provided better conditions for the germination process (Table 3). Again, the increase in temperature was detrimental to lettuce cultivars. From the temperature of $30^{\circ} \mathrm{C}$ there was inhibition of the germination as a consequence of the dormancy induced in the seeds. Similar results were reported by Catão et al. (2014), where they observed a reduction in germination and seed vigor when the germination temperature was raised from 20 to $35^{\circ} \mathrm{C}$. 
In this sense, Nascimento et al. (2012) point out that temperatures in the range of 18 to $21^{\circ} \mathrm{C}$ are the most suitable for germination of lettuce seeds.

When determining the effect of cultivars within each temperature, it is verified that at $20^{\circ} \mathrm{C}$ the cultivars Mimosa Salad Bowl and Curly Cabbage presented the highest rates of germination speed (Table 4). Higher rates indicate that the seeds germinated faster and more efficiently, uniform, being therefore more vigorous (OLIVEIRA et al., 2014).

Table 4. Germination speed index (GSI) of seeds of lettuce cultivars at different temperatures. Janaúba - MG, 2015/2016.

\begin{tabular}{ccccc}
\hline \multirow{2}{*}{ Temperature $\left({ }^{\circ} \mathrm{C}\right)$} & \multicolumn{3}{c}{ Growcrops } \\
\cline { 2 - 5 } & \multirow{2}{*}{ American } & Curly for & Mimosa Salad & Curly Cabbage \\
& $22,9 \mathrm{BCa}$ & $19,2 \mathrm{Ca}$ & $24,67 \mathrm{Aba}$ & $26,80 \mathrm{Aa}$ \\
25 & $8,1 \mathrm{Cb}$ & $22,3 \mathrm{Aa}$ & $10,80 \mathrm{Cb}$ & $14,99 \mathrm{Bb}$ \\
30 & $0,0 \mathrm{Bc}$ & $9,1 \mathrm{Ab}$ & $0,00 \mathrm{Bc}$ & $0,00 \mathrm{Bc}$ \\
\hline
\end{tabular}

Means followed by different letters, upper case in the row and lowercase in the column, differ by the Tukey test at 5\% significance.

At temperatures of 25 and $30^{\circ} \mathrm{C}$, the cultivar Curly for Summer presented the highest values of Germination speed index (GSI). For the other cultivars, the rate of germination was zero due to the absence of germination, which indicates seed dormancy at this temperature. These results corroborate with those found by several authors (ARGYRIS et al., 2011; DENG \& SONG, 2012; CATÃO et al., 2014) when analyzing dormancy in lettuce seeds caused by high temperatures.

Analyzing the effect of temperatures within each grow crops, it was verified that the seeds of the cultivars American, Mimosa Salad Bowl and Curly Cabbage expressed higher GSI at $20^{\circ} \mathrm{C}$. For the cultivar Curly for Summer there was no statistical difference between the temperatures of 20 and $25^{\circ} \mathrm{C}$ (Table 4). It should be noted that the temperature has a great influence on the germination of lettuce seeds mainly during the first hours of germination (NASCIMENTO \& PEREIRA, 2007), so the temperature increase can affect the vigor of the cultivars. Bufalo et al. (2012), working with lettuce seeds of the Great Lakes American under different light conditions, observed higher GSI at temperatures of 20 and $25^{\circ} \mathrm{C}$.

When analyzing the unfolding of cultivars within each temperature, it was observed that at $20^{\circ} \mathrm{C}$ there were no significant differences between cultivars when the percentage of dormant seeds was evaluated (Table 5). 
Table 5. Dormant seeds (\%) of lettuce cultivars at different temperatures. Janaúba - MG, 2015/2016.

\begin{tabular}{ccccc}
\hline & \multicolumn{4}{c}{ Growcrops } \\
\cline { 2 - 5 } Temperature $\left({ }^{\circ} \mathrm{C}\right)$ & American & $\begin{array}{c}\text { Curly for } \\
\text { Summer }\end{array}$ & $\begin{array}{c}\text { Mimosa Salad } \\
\text { Bowl }\end{array}$ & Curly Cabbage \\
\hline 20 & $13 \mathrm{Ac}$ & $2 \mathrm{Ab}$ & $2 \mathrm{Ac}$ & $1 \mathrm{Ab}$ \\
25 & $58 \mathrm{Ab}$ & $4 \mathrm{Cb}$ & $25 \mathrm{Bb}$ & $7 \mathrm{Cb}$ \\
30 & $100 \mathrm{Aa}$ & $70 \mathrm{Ba}$ & $100 \mathrm{Aa}$ & $100 \mathrm{Aa}$ \\
\hline
\end{tabular}

Means followed by different letters, uppercase in the row and lowercase in the column, differ by the Tukey test at 5\% significance.

The seeds of the Americangrow crops submitted to temperature of $25^{\circ} \mathrm{C}$ presented higher percentages of dormant seeds when compared to the other cultivars, thus justifying the low values in the other analyzed variables. At $30^{\circ} \mathrm{C}$, the cultivar Curly for Summer showed the lowest percentage of dormant seeds. When lettuce seeds are exposed to high temperatures, complete inhibition of germination can occur, due to the stiffening of the endosperm that ends up restricting the radicle protrusion (KOZAREWA et al., 2006; NASCIMENTO et al., 2012).Catãoet al. (2014) found that the exposure of lettuce seeds at temperatures above $30^{\circ} \mathrm{C}$ provides increases in the percentage of dormant seeds.

By studying the behavior of temperatures within each cultivar, it is observed that as the temperature increased from 20 to $25^{\circ} \mathrm{C}$ there were significant increases in the percentage of dormant seeds of the cultivars American and Mimosa Salad Bowl. The observed increments were 346 and 1150\%, respectively (Table 5). For the other cultivars, the increments were not significant. However, when the seeds were germinated at $30^{\circ} \mathrm{C}$, there was an increase in the percentage of dormant seeds, independently of the cultivar studied. High percentages of dormant seeds are due to the elevation of temperature that may induce thermodormity in lettuce cultivars. The thermodormity promotes the hardening of the endosperm that ends up limiting the emission of the radicle. The embryo of the lettuce seed is completely enveloped by the endosperm, and must be traversed by the radicle for germination to occur. Thus, the endosperm can delay or prevent seed germination, acting as a physical barrier to radicle emission (SUNG et al., 2008).

It should be pointed out that the identification of cultivars capable of germinating at higher temperatures is of great importance for regions of tropical climate, such as northern Minas Gerais, as it would increase lettuce cultivation period and, consequently, reduce losses in production. However, it was not possible to identify a cultivar with satisfactory germination capacity at high temperatures, yet, the cultivar Curly for Summer was more tolerant among the studied cultivars, and could be an alternative for lettuce improvement programs aiming at the obtaining of cultivars that are tolerant to high temperatures. 


\section{CONCLUSIONS}

The lettuce cultivars present greater germination and vigor when exposed to the temperature of $20^{\circ} \mathrm{C}$, and Curly for Summer is more tolerant to temperatures of 25 and $30^{\circ} \mathrm{C}$.

The temperature of $30^{\circ} \mathrm{C}$ inhibits the germination of the cultivars American, Mimosa Salad Bowl and Curly Cabbage.

\section{REFERENCES}

ABUD, H.F.; ARAUJO, E.F.; ARAUJO, R.F.; ARAUJO, A.V.; PINTO, C.M.F. 2013. Qualidade fisiológica de sementes das pimentas malagueta e biquinho durante a ontogênese. Pesquisa Agropecuária Brasileira, Brasília, v.48, n. 12, p.1546-1553.

ARGYRIS, J.; TRUCO, M. J.; OCHOA, O.; MCHALE, L.; DAHAL, P.; VAN DEYNZE, A.; MICHELMORE, R. W.; BRADFORD, K. J. 2011. A gene encoding an abscisic acid biosynthetic enzyme (LsNCED4) collocates with the high temperature germination locus Htg6.1 in lettuce (Lactuca sp.). Theoretical and Applied Genetics, Bethesda, v.122, p.95-108.

BUFALO, J.; AMARO, A.C.E.; ARAÚJO, H.S. DE; CORSATO, J.M.; ONO, E.O.; FERREIRA, G.; RODRIGUES, J.D. 2012. Períodos de estratificação na germinação de sementes de alface (Lactuca sativa L.) sob diferentes condições de luz e temperatura. Semina: Ciências Agrárias, Londrina, v.33, n.3, p.931-940.

BRASIL. 2009. Ministério da agricultura e Reforma Agrária. Secretaria Nacional de Defesa Agropecuária. Regras para análise de sementes, Brasília: SNAD/DNDV/CLAV, 365p.

CATÃO, H.C.R.M.; GOMES, L.A.A.; SANTOS, H.O. DOS; GUIMARÃES, R. M.; FONSECA, P.H.F.; CAIXETA, F.2014. Aspectos fisiológicos e bioquímicos da germinação de sementes de alface em diferentes temperaturas. Pesquisa Agropecuária Brasileira, Brasília, v.49, n.4, p.316-322.

DENG, Z.; SONG, S. 2012. Sodium nitroprusside, ferricyanide, nitrite and nitrate decrease the thermaldormancy of lettuce seed germination in a nitric oxide-dependent manner in light. South African Journal of Botany, Scottsville, v.78, p.139-146.

FERREIRA, D.F. 2008. SISVAR: um programa para análises e ensino de estatística. Revista Symposium, Lavras, v.6, p.36-41.

KIGEL, J.; GALILI, G. 1995. Seed development and germination. New York: M. Dekker, 853p.

KOZAREWA, I.; CANTLIFFE, D.J.; NAGATA, R.T.; STOFFELLA, P.J. 2006. High maturation temperature of lettuce seeds during development increased ethylene production and germination at elevated temperatures. Journal of the American Society of Horticultural Science, Alexandria, v.131, n.4, p.564-570.

MAGUIRE, J.D. 1962. Speed of germination-aid in selection and evaluation for seedling emergence and vigor. Crop Science, Madison, v.2, n.1, p.176-177.

NASCIMENTO, W. M.; CROD, M.D.; LOPES, A.C.A. 2012. Produção de sementes qualidade fisiológica e identificação de genótipos de alface termotolerantes. Revista Brasileira de Sementes, Londrina, v.34, n.3, p.510-517.

NASCIMENTO, W. M.; PEREIRA, R.S. 2007. Testes para avaliação do potencial fisiológico de sementes de alface e sua relação com a germinação sob temperaturas adversas. Revista Brasileira de Sementes, Londrina, v.29, p.175-179. 
NASCIMENTO, W.M. 2003. Preventing thermoinhibition in a thermosensitive lettuce genotype by seed imbibition at low temperature. Scientia Agricola, Piracicaba, v.60, n.3, p.477-480.

NASCIMENTO, W.M.; CANTLIFFE, D.J. 2002. Germinação de sementes de alface sob altas temperaturas. Horticultura Brasileira, Brasília, v.20, n.1, p.103-106.

NASCIMENTO, W. M. 2000. Envolvimento do etileno na germinação de sementes. Revista Brasileira de Fisiologia Vegetal, São Carlos, v. 12, p. 163-174.

OLIVEIRA, M.B. de; DAVID, A.M.S. S. de; AMARO, H.T.R.; ASSIS, M.O.; RODRIGUES, B.R.A.; ASPIAZÚ, I.; CARVALHO, A.J. 2014. Épocas de colheita e qualidade fisiológica de sementes de crambe. Semina: Ciências Agrárias, Londrina, v.35, p.1785-1792.

PINHEIRO, G.S.; ANGELOTTI, F.; SANTANA, C.V. DA S.; DANTAS, B.F.; COSTA, N.D. 2014. Efeito da temperatura sobre a germinação de sementes de cebola. Scientia Plena, Sergipe, v.10, n.11, p. 1-6.

SUNG, Y.; CANTLIFFE, D.J.; NAGATA, R.T.; NASCIMENTO, W.M. 2008. Structural changes in lettuce seed during germination at high temperature altered by genotype, seed maturation temperature, and seed priming. Journal of the American Society of Horticultural Science, Alexandria, v.133, n.2, p.300-311.

Receivedin September 01,2016

Accepted in August 24, 2017 